\title{
Analysis of Community Participation on Sustainable Development Planning of Geopark Silokek Tourism at Sijunjung Regency
}

\author{
Zul Azhar ${ }^{1}$, Ali Anis ${ }^{2}$, Hari Setia Putra ${ }^{3 *}$, Jemi Juneldi ${ }^{4}$ \\ 1, 2, 3, 4 Universitas Negeri Padang, Padang, Indonesia \\ *Corresponding author. Email: hari.putra@fe.unp.ac.id
}

\begin{abstract}
This study aims to determine the level of community participation in sustainable development of the Silokek Geopark tourism in Sijunjung Regency. The data was obtained by conducting a survey to the local community, then giving a questionnaire and conducting interviews. This study also analyzes the effect of economic activity, poor road conditions and communication networks, investment, assistance from the government in promotion and political stability on tourism development. From the research results, it was found that community participation in the planning stage was at the informational level, while at the implementation stage it was at the consultation level, then the monitoring and evaluation stage was at the placation level. The regression results show that economic activity, investment and government assistance for promotion have a positive and significant effect on participation in tourism development. Meanwhile, damaged roads, poor communication networks and political stability have a negative relationship with participation in tourism development, but only the political stability variable has a significant influence on participation in tourism development. This is a recommendation for the government in developing tourism to pay attention to road access and communication so that development can run well. Likewise, with politics, the community hopes that there will be no political element from the government to the people who only seek profit in tourism development but do not pay attention to the environment and society.
\end{abstract}

Keywords: Sustainable development, Arnstein`s typology, Investment, Government assistances.

\section{INTRODUCTION}

Tourism development in several regions or countries in recent years has received serious attention. The experiences of several regions or countries in exploiting tourism potential have shown significant results in boosting their economies. The benefits that are felt can generally be seen from the increase in people's income, the more job opportunities are opened, the increase in community welfare and so on. Research conducted by [1] regarding the impact of tourism on the welfare of the surrounding community concludes that people who work in sectors directly related to tourism have a much higher consumption value compared to people who work in the non-tourism sector where consumption is used as an indicator. measure the welfare of society. Furthermore, [2] states that there is a positive relationship between tourism development and improving the quality of life of the community as well as the direct contribution of the travel and tourism sector to GDP and employment. If viewed more broadly, research [3] shows that an increase in the tourism sector contributes to GDP growth in Pakistan. So that the tourism sector has an important contribution and role in the economy of a country.

There are several things that make the tourism sector an important contribution and role in the economy. When the government and the surrounding community take advantage of natural wealth or local heritage in developing tourism, the economic activity in the area will increase. The tourism development will encourage various types of related businesses to develop as well. When tourists visit a tourist attraction, they will spend part of their income on consumption and accommodation costs such as lodging and transportation during a tourism trip. This will encourage various economic activities to emerge, such as an increase in the food and beverage business, transportation services and travel agents, lodging, creative or handicraft industries, entertainment businesses and so on. Job opportunities will be opened more widely and will reduce unemployment in the area. Community income will increase so that it will improve community welfare.

To get the maximum benefit from tourism activities, the quality and availability of tourism facilities must be 
one of the priorities in the development of tourism objects. When tourists come to visit tourist objects, they will pay attention to the quality of management and the availability of existing facilities around these attractions. When tourists feel happy and satisfied with the complete services and facilities available, they will be satisfied and will have the desire to visit these attractions again. In addition, they will voluntarily promote these attractions and recommend them to their family and friends. Thus, this will affect the sustainability of tourism activities in the area. This is also evidenced by research [4] which concluded that the key to the sustainability of tourist destinations in Pahang is the satisfaction of tourists, both domestic and foreign tourists.

In order to create a sustainable development of tourist objects, it requires strategic steps involving several related parties such as the government, surrounding communities and business actors in the tourism sector. These three parties have a direct relationship with the development of tourist objects. The government has a more dominant role in making regulations and providing facilities such as road infrastructure, parking lots, the availability of information and communication access, and other facilities. Research conducted by [5] states that infrastructure has a significant positive effect on tourism development. The higher the scale of infrastructure or the availability of infrastructure, the higher the tourism development will be. In addition, the availability of access to information and communication also has a positive effect on tourism development. This is because the availability of infrastructure and supporting facilities is closely related to the convenience that tourists get when visiting the area. When they get facilities such as complete infrastructure and facilities, it will create their own satisfaction for tourists when visiting.

The next party that is closely related to tourism development is the surrounding community. When tourists visit a tourist attraction, they will interact directly with the lives of the surrounding community. The treatment and hospitality of the surrounding community will have an influence on the assessment and satisfaction of tourists when visiting tourist objects. Research conducted by [6] concludes that the behavior and attitudes of the surrounding community in responding to tourism activities are one of the determinants of the sustainability of tourist attraction activities. This is based on the attitude of the surrounding community in interacting with visiting tourists to determine the perceptions felt by tourists. When tourists are treated well, warmly welcomed by the community and feel guaranteed of their security and safety, they will feel satisfied with their tour and have an impact on their desire to visit and promote to their friends and relatives.

Other parties that have an important role in tourism development are business actors related to tourism, such as providing travel and transportation services, food and beverage business actors, entertainment service providers and tourist attraction rides, business owners in the creative handicraft industry and business actors. other. When tourists visit a tourist attraction, they will spend part of their income to meet their accommodation needs during a tour. So that the quality of business actors such as the services they receive will affect their perceptions in assessing tourist objects in the area concerned. Research conducted by [7] which examines the development of a tourist destination based on the competitiveness and innovation of the tourism companies involved who see the relationship between tourism development and the knowledge and innovation of service providers related to activities tourism. The results of his research indicate that the knowledge and innovation of service providers related to tourism are the dominant factors affecting tourism development. The higher the competition and innovation from service providers related to tourism, it will encourage tourism development. Thus, it can be seen that business actors who have a direct relationship with tourist objects play an important role in the sustainability of tourist objects.

In the framework of developing tourism, the involvement and integration of the surrounding community, government and business actors plays an important role. When the facilities and infrastructure related to tourist objects are complete, the surrounding community responds positively to the existence of tourism activities and related businesses are of good quality, it will impact on satisfaction and good perceptions of visiting tourists. Tourists who are satisfied and feel happy with the tour will have an impact on their desire to make return tourist visits or promote these attractions to their relatives and friends. So that the sustainability of the development of tourist objects can be carried out properly and have an impact on increasing income and the welfare of the surrounding community as the final goal to be achieved. Therefore, the determinants of the development of tourist objects that can be seen based on the perceptions and behavior of the surrounding community, the role of the government and the quality of services from related business actors must receive serious attention so that the development of tourist objects can provide maximum contribution in improving the welfare of the surrounding community.

\section{METHOD}

The location of this research was carried out in the Silokek Geopark tourist area which is located in Nagari Silokek, Sijunjung Regency which has 2 Jorong namely Jorong Sangkiamo and Jorong Tanjung Medan. Research permits and recommendations were obtained since June 2020, and immediately conducted a survey in the same month. This research is descriptive qualitative with survey method, where the research is qualitative aims to describe, summarize various conditions, situations, phenomena, social realities existing in society which is the object of research and displays it as 
a picture about certain conditions, situations or phenomena. Data collected in the study qualitative in the form of main data that comes from words and actions, while data written, photograph and statistics are additional data. Data obtained from a survey conducted to community using questionnaires and interviews with the number of respondents is 320 .

Based on total statistical data the population in Nagari Silokek is 1,244 people. By using a formula Slovin found that there were 400 respondents. However, not all selected samples were willing to fill out the questionnaire because limited time and the number of people working, the respondent selected at a location that has been determined based on his willingness to be involved in research to answer the questions that exist at questionnaire, this technique is also known as convenience or opportunity sampling. Based on the sample selection stage, 320 people were selected local community respondents who were willing to answer questions around the object of research. This sampling technique was chosen because when the research was carried out, there was a Covid-19 pandemic society shuts itself off from outsiders. Most of the respondents are many willing to answer questionnaire questions, object to writing identity because there are concerns from respondents that cannot be explained. Informants: the method of selecting samples for informants is done by using purposive sampling or purposive sample selection and Snowball Sampling, or selection informants through referrals provided by previous informants.

In analyzing the level of community participation, it was carried out using 8 (eight) Arnstein steps that describe the level of community participation, including Manipulation, Therapy, Informing, Consultation, Placation, Partnership, Delegated Power and Citizen Control. The analysis phase for this purpose is to provide questions related to community participation in planning, implementing, and monitoring the evaluation of tourism object development programs through a questionnaire. Each question is given 8 (eight) answer choices adjusted to the level of participation according to Arnstein. Each answer is given a score of 1 to a score of 8 . The higher the score indicates the higher the level of community participation, conversely the lower the score, the lower the level of community participation (non-participation).

To determine the level of participation is done by determining the score of each of the Arnstein rungs at each stage of planning, implementing, and monitoring program evaluation, by first determining the maximum and minimum scores. The number of questions for planning is 1 (one), implementation is 3 (three), and monitoring and evaluation is 1 (one). With the formula of minimum score is number of question $\mathrm{x} 1 \mathrm{x}$ number of respondents, where the formula for maximum score is number of question $\mathrm{x} 8 \mathrm{x}$ number of respondents.
Table 1. Maximum and Minimum Score of Arnstein Typology

\begin{tabular}{|l|c|c|}
\hline Stages & Score & Result \\
\hline \multirow{2}{*}{ Planning } & Min & 320 \\
\cline { 2 - 3 } & Max & 2560 \\
\hline \multirow{2}{*}{ Implementation } & Min & 960 \\
\cline { 2 - 3 } & Max & 7680 \\
\hline \multirow{2}{*}{ Monitoring and Evaluation } & Min & 320 \\
\cline { 2 - 3 } & Max & 2560 \\
\hline
\end{tabular}

Source: Author`s Processed Results

Furthermore, to determine the level of community participation, it is adjusted to the level of participation according to the Arnstein Ladder by determining the interval for each rung. The interval is calculated by the formula of interval is maximum score minus minimum score and divided by 8 (eight).

Table 2. The Interval of Each Stage of the Arnstein Typology

\begin{tabular}{|l|c|}
\hline Stages & Interval \\
\hline Planning & 280 \\
\hline Implementation & 840 \\
\hline Monitoring and Evaluation & 280 \\
\hline
\end{tabular}

Source: Author's Processed Results

The level of community participation is known by calculating the total score obtained from the overall answers of the respondents. The total score of acquisition at each stage determines the level of community participation at that stage. The results of the score calculation are put into the appropriate category according to Arnstein's ladder. Researchers want to see how the influence of economics activity (X1), road conditions and communication networks (X2), investments (X3) the role of government in promoting(X4), and political stability (X5) on community participation in the development of tourist objects (Y) by using OLS (Ordinary Least Square) includes the partial test and simultaneous test. First, use the test on the level of achievement of the respondent to describe the character of each research variable. The level of achievement of respondents is classified into the following groups:

Table 3. Level of Respondent Achievement (LRA) Classification

\begin{tabular}{|c|l|c|}
\hline No. & \multicolumn{1}{|c|}{ LRA } & Criteria \\
\hline 1 & $<56 \%$ & Not Good \\
\hline 2 & $56 \%-75 \%$ & Good Enough \\
\hline 3 & $76 \%-100 \%$ & Good \\
\hline
\end{tabular}

Source: Author's Processed Results

With the variables used in this study are variables from the survey results with the type of ratio data. Multiple Regressions model can be formed as follows:

$Y=\alpha_{0}+\beta_{1} X_{1}+\beta_{2} X_{2}+\beta_{a} X_{a}+\beta_{4} X_{4}+\beta_{5} X_{5}+\varepsilon$

Where:
$\alpha, \beta \quad$ : regression coefficients
$\varepsilon \quad:$ Error disturbance 


\section{RESULTS AND DISCUSSION}

\subsection{Level of Respondent Achievement}

From the result of processing data show that all variables are in good criteria, where LRA value for Y1 (91,91\%), X1 (85,09\%), X2 (88,75\%), X3 (88,97\%) X4 $(90,94 \%)$ and X5 $(82,94 \%)$.

\subsection{Level of Community Participation}

Table 4. Level of Community Participation

\begin{tabular}{|l|l|}
\hline Stages & \multicolumn{1}{c|}{ Level } \\
\hline Planning & Informing \\
\hline Implementation & Consultation \\
\hline Monitoring and Evaluation & Placation \\
\hline Source: Author`s Processed Results
\end{tabular}

At the planning stage, community are asked to know their involvement in tourism development planning, from the results of the interviews, it was found that $70 \%$ of visitors had been involved in tourism development efforts, $12 \%$ stated that there were programs socialized by the government and the community, and $18 \%$ claimed not to know. From the analysis, community participation in the planning stage is at the informing level. Informing, at this level the government has provided information about rights, responsibilities and choices to society. However, information is one-way from government to society, with no opportunity to provide feedback and negotiation. Information is given usually for provide the final stages in planning, so that communities have little chance of influencing programs designed "to their advantage." The most frequently used tools for this kind of one-way communication are news media, pamphlets, posters, and meetings.

At the implementation stage, community are asked questions about involvement in implementing tourism development programs, overcoming problems related to tourism, community are currently at the consultation stage. Consultation, at this stage the government asks for public opinion through surveys of public attitudes, meetings and public hearings, but does not guarantee that these opinions and ideas will be taken into account. Participation was measured by how many came to the meeting and brought flyers home, or answered questionnaires.

At the monitoring and evaluation stage, community are asked whether they participate in providing evaluation and monitoring of tourism development efforts. At this stage the visitors are at the placation level. Placation, at this level public participation by placing representatives of the poor in public bodies, but there is no guarantee of that vote they will be counted towards the constituency, which is the composition of the elite representative from society is only limited to having clear and direct access to decision making, but power over planning and programming as well the final decision remains with the government.

\subsection{Regression Result Analysis}

From the table 5 below show the analysis in this research that is the influence of economics growth, road condition, investment, role of government in promoting, political stability on community participation in the development of tourist object.

Table 5. Model Estimation Results

\begin{tabular}{|c|r|r|r|c|}
\hline Variable & Coefficient & \multicolumn{1}{c|}{ Std. Error } & t-Statistic & Prob. \\
\hline C & 4.166366 & 0.459312 & 9.070894 & 0.0000 \\
\hline X1 & 0.095180 & 0.036853 & 2.582664 & 0.0103 \\
\hline X2 & -0.031135 & 0.051739 & -0.601784 & 0.5478 \\
\hline X3 & 0.073301 & 0.052929 & 1.384894 & 0.0001 \\
\hline X4 & 0.117553 & 0.068383 & 1.719031 & 0.0066 \\
\hline X5 & -0.168422 & 0.035322 & -4.768159 & 0.0000 \\
\hline
\end{tabular}

Source: Author`s Processed Results

The equation model can be arranged as follows: $\mathrm{Y}=4,166366+0,095180 \mathrm{X}_{1}-0,031135 \mathrm{X}_{2}+0,073301$ $X_{3}+0,117553 X_{4}-0,168422 X_{5}$

From the result above can be seen, economics activity, investments, the role of government in promoting has positive relationship and significant influence on community participation in the development of tourist objects. However, road conditions and communication networks and political stability right now has negative relationship, but only political stability that has significant relationship. Research conducted by [8] regarding The Influence of Tourism Dependency on Tourism Impact and Development Support Attitude concluded that people who have an economic dependence on the tourism sector, such as employment from tourism, have a behavior in encouraging tourism development.

Research conducted by [9] regarding Impact of Road Infrastructure On Tourism Development in Kosovo states that road shortages or poor conditions and low road safety have an impact on reducing the number of visitors. Also the research conducted by [5] on ICT, infrastructure, and tourism development in Africa. states that information and technology (ICT) has a significant positive effect on the development of tourist objects. The higher the level of internet and mobile cellular usage, the higher the level of tourism demand in the area. This is because the high level of information and technology usage will make tourism management more effective as well as high connectivity through internet visibility.

Research conducted by [10] with the title The Effect of Tourism Investment On Tourism Development and $\mathrm{CO} 2$ Emissions: Empirical Evidence from The $\mathrm{EU}$ Nations States that investment in the tourism sector has a significant and positive impact on tourism development. Investment in the tourism sector encourages growth in tourism-related industries so as to guarantee the sustainability of tourism development.

Research conducted by [11] regarding Marketing Promotion Financing and Tourism Development: The 
Case of Mauritius shows that promotional efforts undertaken by the government have a positive impact on tourism development in Mauritius. Research conducted by [12] regarding the Impacts of political instability on the tourism industry in Ukraine concluded that political instability has a negative impact on industries related to tourism because political instability causes a decrease in income, the number of tourists visiting drops dramatically and increase costs.

\section{CONCLUSION}

Level of community participation in planning, implementation and monitoring program evaluation is low. The results of the analysis are according to the stairs Arnstein points out that in the planning stage at the informing level, while the implementation stage is in consultation level, monitoring and evaluation stage at the placation level. From regression analysis can be seen, economics activity, investments, the role of government in promoting has positive relationship and significant influence on community participation in the development of tourist objects. However, road conditions and communication networks and political stability right now has negative relationship, but only political stability that has significant relationship. Community participation means empowering the community, community participation in planning activities and implementation of development programs/ projects and is the actualization of the availability and willingness of the community to sacrifice and contribution to the implementation of development programs.

\section{REFERENCES}

[1] M. E. Yergeau, "Tourism and local welfare: A multilevel analysis in Nepal's protected areas," World Dev., vol. 127, p. 104744, 2020, doi: 10.1016/j.worlddev.2019.104744.

[2] A. Băndoi, E. Jianu, M. Enescu, G. Axinte, S. Tudor, and D. Firoiu, "The Relationship between development of tourism, quality of life and sustainable performance in EU countries," Sustain., vol. 12, no. 4, pp. 1-24, 2020, doi: $10.3390 /$ su12041628.

[3] A. Khan, S. Bibi, A. Lorenzo, J. Lyu, and Z. U. Babar, "Tourism and development in developing economies: A policy implication perspective," Sustain., vol. 12, no. 4, pp. 1-19,
2020, doi: 10.3390/su12041618.

[4] M. F. Sukiman, S. I. Omar, M. Muhibudin, I. Yussof, and B. Mohamed, "Tourist Satisfaction as the Key to Destination Survival in Pahang," Procedia - Soc. Behav. Sci., vol. 91, pp. 78-87, 2013, doi: 10.1016/j.sbspro.2013.08.404.

[5] O. Adeola and O. Evans, "ICT, infrastructure, and tourism development in Africa," Tour. Econ., vol. 26, no. 1, pp. 97-114, 2020, doi: $10.1177 / 1354816619827712$.

[6] M. F. B. López, N. R. Virto, J. A. Manzano, and J. G. M. Miranda, "Residents' attitude as determinant of tourism sustainability: The case of Trujillo," J. Hosp. Tour. Manag., vol. 35 pp. $\quad 36-45, \quad 2018, \quad$ doi: 10.1016/j.jhtm.2018.02.002.

[7] K. Borodako, J. Berbeka, and M. Rudnicki, "The potential of local KIBS companies as a determinant of tourism development in Krakow," Tour. Econ., vol. 20, no. 6, pp. 1337-1348, 2014, doi: 10.5367/te.2013.0351.

[8] C.-H. Hung and M.-T. Wu, "The Influence of Tourism Dependency on Tourism Impact and Development Support Attitude," Asian J. Bus. Manag., vol. 5, no. 2, pp. 88-96, 2017, doi: 10.24203/ajbm. v5i2.4594.

[9] R. Mazrekaj, "Impact of road infrastructure on tourism development in Kosovo," Int. J. Manag., vol. 11, no. 4, pp. 466-474, 2020, doi: 10.34218/IJM.11.4.2020.045.

[10] S. R. Paramati, M. S. Alam, and C. K. M. Lau, "The effect of tourism investment on tourism development and $\mathrm{CO} 2$ emissions: empirical evidence from the EU nations," J. Sustain. Tour., vol. 26, no. 9, pp. 1587-1607, 2018, doi: 10.1080/09669582.2018.1489398.

[11] B. Seetanah and R. V. Sannassee, "Marketing Promotion Financing and Tourism Development: The Case of Mauritius," J. Hosp. Mark. Manag., vol. 24, no. 2, pp. 202-215, 2015, doi: 10.1080/19368623.2014.914359.

[12] S. Ivanov, M. Gavrilina, C. Webster, and V. Ralko, "Impacts of political instability on the tourism industry in Ukraine," J. Policy Res. Tour. Leis. Events, vol. 9, no. 1, pp. 100-127, 2017, doi: 10.1080/19407963.2016.1209677. 